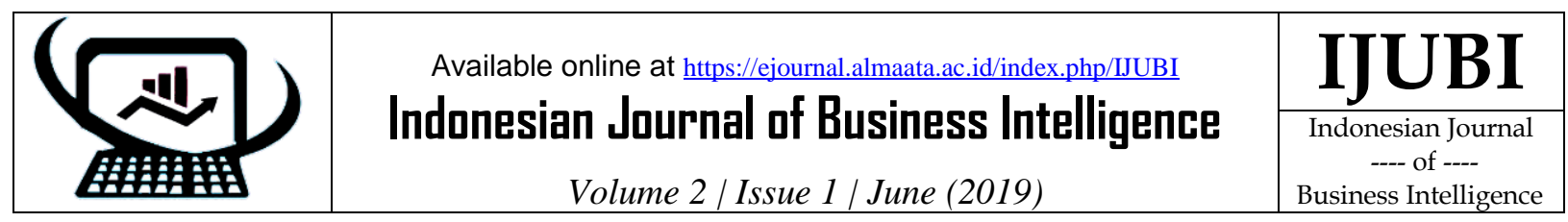

\title{
PERANCANGAN SISTEM PELELANGAN BERITA BERBASIS WEBSITE
}

Deden Hardan Gutama

Teknik Informatika, Fakultas Komputer, Universitas Alma Ata hardan@ngewangi.com

J1. Brawijaya No. 99, Yogyakarta 55183

\section{Keywords:}

Websites, making web sales news, auctions, PHP.

\section{Kata Kunci}

Website, pembuatan web pelelangan berita, pelelangan, $\mathrm{PH}$.

\begin{abstract}
Events around the community such as accidents, education news, traveling, and not a few sports that they document for personal use or for sale to a company broadcasters such as radio stations, television stations, and newspapers. But not as easy as imagined to sell news / information that they get, they have to wait for quite a long time even to no certainty of not a few they get such emails not returned, and others. The second problem is in corporate broadcasters, namely getting actual news, updates, and reliable. In getting actual news, updates, and reliable companies entrust their reporters to the designated location, with this system because of the time constraint journey where time is a major factor in getting the news that "update". Looking at these problems, the authors wanted to provide a solution that is "System Design Sales News Web Based". This solution is expected to facilitate the sale of the news and get the actual news, updates, and reliably using the PHP programming language.
\end{abstract}

Kejadian disekitar masyarakat seperti kecelakaan, berita pendidikan, traveling, dan olah raga tak sedikit yang mereka dokumentasikan untuk keperluan pribadi atau untuk dijual keperusahaan penyiar seperti stasiun radio, stasiun televisi, dan surat kabar. Namun tak semudah yang dibayangkan untuk menjual berita/informasi yang mereka dapatkan, mereka harus menunggu waktu yang cukup lama bahkan ke tidak pastian tak sedikit mereka dapatkan seperti email yang tidak dibalas, dan lain-lain. Permasalahan kedua ada pada perusahaan penyiar, yaitu mendapatkan berita yang aktual, update, dan terpercaya. Dalam mendapatkan berita yang aktual, update, dan terpercaya perusahaan mempercayakan wartawan mereka yang ditunjuk ke lokasi, dengan sistem ini waktu menjadi kendala karena proses perjalanan yang dimana waktu adalah faktor utama dalam mendapatkan berita yaitu "update". Melihat permasalahan tersebut, penulis ingin memberikan solusi yaitu "Perancangan Sistem Pelelangan Berita Berbasis Web". Diharapkan solusi ini dapat mempermudah pelelangan berita dan mendapatkan berita yang aktual, update, dan terpercaya menggunakan bahasa pemrograman PHP.

\section{Pendahuluan}

Semakin banyaknya pengguna internet, semakin banyak pula website yang lahir di dunia maya mulai dari website jual beli hingga website portal berita. Banyaknya website portal berita yang lahir ini membuat semakin ketat persaingan perusahaan penyedia berita 40 "Deden Hardan Gutama" sehingga perusahaan harus semakin aktual, update, dan terpercaya dalam menyediakan berita kepada para pembaca. Bahkan kantor penyedia berita seperti kompas, dan lain lain sering menerima kiriman berita via email dari koresponden karena karyawan mereka kurang 
update dalam mencari berita seperti berita bencana alam.

Namun untuk menjadi koresponden tidaklah mudah, calon koresponden harus menghubungi penyedia berita, dan memenuhi berbagai persyaratan yang diajukan oleh perusahaan penyedia berita seperti pengisian form perjanjian, dan form identitas. Setelah koresponden melengkapi segala syarat yang ditentukan perusahaan penyedia berita barulah dapat mengirim berita dalam format tulisan atau vide melalui FTP (File Transfer Protocol) dan melalui Email sebagai verifikasi sekaligus berita dalam bentuk tulisan. Selepas berita dikirimkan, dan pembayaran fee, koresponden dapat mengirimkan berita kembali akan tetapi diharuskan untuk melengkapi syarat tersebut kembali.

Berdasarkan latarbelakang diatas penulis mengambil penelitian berupa perancangan sistem pelelangan berbasis website dimana penulis sangat mengharapkan hasil penelitian ini dapat mempermudah perusahaan penyedia berita untuk mendapatkan berita serta mempermudah koresponden dalam menjual berita mereka.

\section{Landasan Teori}

\section{Flowchart}

Flowchart adalah merupakan alat berupa simbol yang berguna menggambarkan physical sistem, simbol-simbol bagan alur ini dapat menggambarkan secara pasti arti fisik dari sebuah sistem seperti simbol terminal, hard disk, laporan-laporan, dan lain lain-lain [1]. Kegunaan dari flowchart itu sendiri adalah sebagai penolong analisis dan programmer dalam sebuah proyek sistem informasi untuk memecahkan masalah yang dihadapi oleh user ke dalam segmen-segmen yang lebih detail.

\section{Proses Modeling Data Flow Diagram}

Data Flow Diagram (DFD) merupakan suatu network yang menjelaskan suatu sistem terkomputerisasi, manualisasi, atau gabungan dari kedua tersebut, yang penggambarannya disusun dalam bentuk kumpulan komponen sistem yang saling berhubungan sesuai aturan baku.
Kelebihan dalam menggunakan DFD adalah memungkinkan kita untuk menggambarkan sebuah system informasi dari level yang sangat tinggi kemudian diuraikan menjadi level yang sangat rendah (dekomposisi). Sedangkan kekurangan dari DFD adalah tidak menunjukkan prosesmlooping, proses keputusan, dan proses penghitungan [2].

\section{Pelelangan}

Pengertian dari lelang adalah penjualan barang yang terbuka untuk khalayak umum atau khusus dengan penawaran harga secara tertulis dan/atau lisan yang semakin meningkat atau menurun untuk mencapai harga tertinggi yang didahului dengan pengumuman pelelang.

Referensi [3] Jenis pelelangan.

\section{Lelang Noneksekusi Sukarela}

Adalah lelang untuk melaksanakan penjualan barang milik perorangan, kelompok masyarakat atau Badan Swasta yang dilelang secara sukarela oleh pemiliknya.

Yang termasuk lelang Noneksekusi Sukarela adalah :

a. Lelang yang dilakukan atas kehendak pemiliknya sendiri (perorangan, swasta)

b. Lelang Aset BUMN/BUMD berbentuk Persero

c. Lelang Aset milik Bank Dalam Likuidasi berdasarkan PP Nomor 25 Tahun 1999 tentang pencabutan izin usaha, pembubaran dan likuidasi Bank.

Harga limit dapat bersifat terbuka / tidak rahasia atau dapat bersifat tertutup/ rahasia sesuai keinginan Penjual/ Pemilik Barang

\section{Lelang Eksekusi}

Adalah lelang untuk melaksanakan kep utusan/penetapan pengadilan atau dokumen-dokumen lain yang sesuai dengan peraturan perundang- 
undangan yang berlaku, dipersamakan dengan itu, dalam rangka membantu penegakan hukum, antara lain : lelang eksekusi fiducia dan lelang eksekusi pasal 6 Undang-Undang Hak Tanggungan (UUHT No.4 Tahun 1996).

Pasal 6 UUHT No. 4 tahun 1996, yaitu apabila debitur cidera janji, Pemegang Hak Tanggungan tingkat Pertama mempunyai hak untuk menjual obyek Hak Tanggungan atas kekuasaan sendiri melalui pelelangan umum serta mengambil pelunasannya dari hasil tersebut. Harga limit bersifat terbuka/tidak rahasia dan harus dicantumkan dalam pengumuman lelang.

3. Lelang Non Eksekusi Wajib

Adalah lelang untuk melaksanakan penjualan barang milik negara/daerah sebagaimana dimaksud dalam UndangUndang Nomor 1 Tahun 2004 Tentang Perbendaharaan Negara atau barang milik Badan Usaha Milik Negara/Daerah (BUMN/D) yang oleh peraturan perundang-undangan diwajibkan untuk dijual secara lelang, termasuk kayu dan hasil hutan lainnya dari tangan pertama.

\section{Basis Data}

Basis data adalah sekumpulan data yang terdiri dari satu atau lebih tabel yang saling berhubungan [4] . Relasi biasanya ditunjukkan dengan icon kunci dari tiap file yang ada. Dalam satu file terdapat record-record yang sejenis, sama besar, sama bentuk, yang merupakan satu kumpulan entitas yang seragam.

\section{Operasi-operasi di dalam Basis Data}

Operasi-operasi yang dilakukan di dalam basis data adalah [5] :

Tabel 2.3 Tabel perintah basis data

\begin{tabular}{|l|l|l|}
\hline No. & Perintah & Keterangan \\
\hline 1. & $\begin{array}{l}\text { CREAT } \\
\text { DATABASE }\end{array}$ & Membuat Database \\
\hline 2. & $\begin{array}{l}\text { ALTER } \\
\text { DATABASE }\end{array}$ & Mengubah database \\
\hline
\end{tabular}

42 "Deden Hardan Gutama"

\begin{tabular}{|l|l|l|}
\hline 3. & DROP DATABASE & Menghapus database \\
\hline 4. & CREAT TABLE & Membuat tabel \\
\hline 5. & ALTER TABLE & $\begin{array}{l}\text { Mengubah struktur } \\
\text { tabel }\end{array}$ \\
\hline 6. & DROP TABLE & Menghapus tabel \\
\hline 7. & CREATE VIEW & Membuat view \\
\hline 8. & ALTER VIEW & Mengubah view \\
\hline 9. & DROP VIEW & Menghapus view \\
\hline 10. & $\begin{array}{l}\text { CREATE } \\
\text { PROCEDURE }\end{array}$ & $\begin{array}{l}\text { Membuat stored } \\
\text { procedure }\end{array}$ \\
\hline 11. & $\begin{array}{l}\text { ALTER } \\
\text { PROCEDURE }\end{array}$ & $\begin{array}{l}\text { Mengubah stored } \\
\text { procedure }\end{array}$ \\
\hline 12. & $\begin{array}{l}\text { DROP } \\
\text { PROCEDURE }\end{array}$ & $\begin{array}{l}\text { Menghapus stored } \\
\text { procedure }\end{array}$ \\
\hline 13. & CREAT TRIGGER & Membuat trigger \\
\hline 14. & ALTER TRIGGER & Mengubah trigger \\
\hline 15. & DROP TRIGGER & Menghapus trigger \\
\hline 16. & CREATE INDEX & Membuat index \\
\hline 17. & DROP INDEX & Menghapus index \\
\hline 18. & SELECT & $\begin{array}{l}\text { Menampilkan } \\
\text { dari tabel }\end{array}$ \\
\hline 19. & COMMIT & $\begin{array}{l}\text { Menuliskan } \\
\text { perubahan ke dalam } \\
\text { disk }\end{array}$ \\
\hline 20. & ROLLBACK & $\begin{array}{l}\text { Membatalkan } \\
\text { perubahan } \\
\text { dilakukan } \\
\text { perintah } \\
\text { yang terakhir }\end{array}$ \\
\hline & &
\end{tabular}

\section{Tipe database}

Tipe database dibedakan menjadi 7 yaitu [5] :

1. Numeric
a. Bgint
b. Int
c. Smallint
d. Tinyint
e. Bit
f. Decimal dan numeric

\section{Date Time}

\section{a. Datetime}

Tanggal dan waktu dari 1 Januari 1753 sampai 31 Desember 9999.

\section{b. Smalldatetime}

Tanggal dan waktu dari 1 Januari 1900 sampai 6 Juni 2079.

\section{Money}

Tipe data nilai mata uang.

4. Numeric Precission 
a. Float

Bilangan presisi dari -179E + 308 sampai $179 \mathrm{E}+308$.

b. Real

Bilangan presisi dari $-3.40 \mathrm{E}+38$ sampai $3.40 \mathrm{E}+38$.

\section{Unicode Character Strings}

a. Nchar

Karakter unicode dengan ukuran panjang tetap 4.000 karakter.

b. Nvarchar

Karakter dengan panjang tidak tetap hingga 4.000 karakter.

c. Ntext

Karakter dengan panjang tidak tetap hingga 1.073.741.823 karakter.

6. Binary Strings

a. Binary

Ukuran tetap data binary hingga 8.000 bytes.

b. Varbinary

Ukuran panjang tidak tetap data binary hingga 8.000 bytes.

c. Image

Ukuran tidak tetap data binary hingga 2.147.483.647 bytes.

7. Strings

a. Char

Field berisi karakter dengan ukuran panjang tetap dengan panjang maksimum 8.000 karakter.

b. Varchar

Field berisi karakter dengan panjang ukuran tidak tetap dengan panjang maksimum 8.000 karakter.

c. Text

Variabel berisi karakter dengan ukuran panjang sampai 2.147.483.647 karakter.

\section{Metode}

Pada penelitian ini menggunakan metode waterfall dimana metode ini memiliki beberapa tahapan yang harus dilakukan secara berurutan [6].

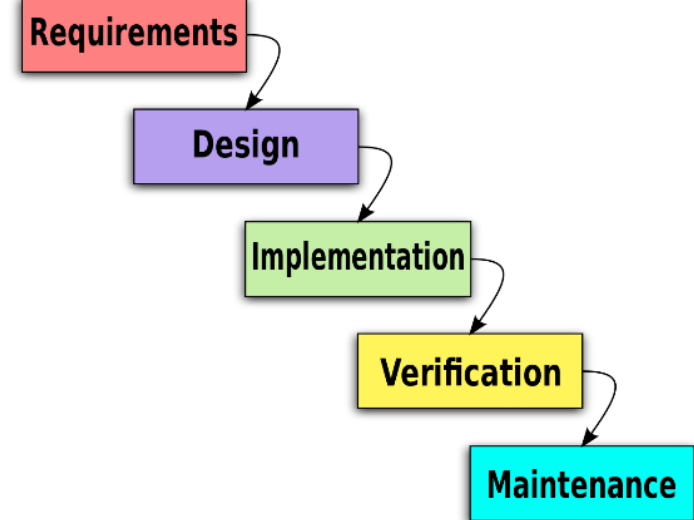

Gambar 1. Tahapan waterfall

\section{Tahap inisiasi}

Adalah analisa kebutuhan sistem yang akan dibuat dan harus dapat dimengerti oleh klien dan developer. Pada tahap ini klien harus dapat menjelaskan dan mendefinisikan tujuan dari sistem yang ingin dibangun. Sebagai developer harus dapat menangkap maksud klien mengenai sistem yang akan di bangun dan juga memberikan saran dan mungkin juga kendala terhadap sistem yang akan dibangun tersebut. Dokumen yang dihasilkan pada tahapan ini menjadi dasar kontrak kerja antara klien dengan developer.

\section{Tahap desain sistem}

Pada tahap ini developer merancang suatu arsitektur sistem berdasarkan hasil dari tahap sebelumnya yaitu tahap inisiasi.

\section{Tahap implementasi}

Adalah tahapan dimana keseluruhan desain sistem yang telah disusun sebelumnya akan diubah menjadi kode-kode program dan modul-modul yang nantinya akan diintegrasikan menjadi sebuah sistem yang lengkap sesuai dengan kontrak kerja.

\section{Tahap integrasi dan testing.}

Pada tahap ini sistem yang sudah dibuat akan diintegrasikan dan di test untuk menguji apakah sistem tersebut telah berfungsi dengan 
baik dan yang tidak kalah penting adalah sesuai dengan kontrak yang telah disetujui.

\section{Tahap pemeliharaan}

Pada tahapan ini instalasi dan proses perbaikan sistem dilakukan apabila ditemukan adanya kesalahan/bug yang tidak ditemukan pada tahap testing.

\section{Hasil dan Pembahasan}

\section{Tahap inisiasi}

Pada tahapan ini peneliti merumuskan kebutuhan sistem dan mendokumentasikan dalam bentuk proses bisnis.

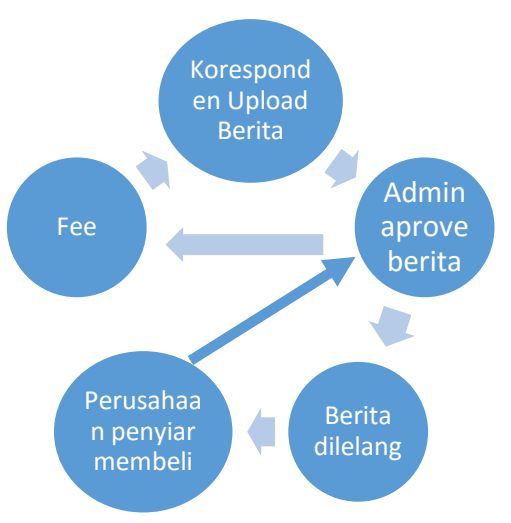

Gambar 2. Proses Bisnis

\section{Tahap desain sistem}

Proses bisnis yang telah dibentuk kemudian di breakdown menjadi lebih rinci yang kemudian dituangkan dalam analisis kebutuhan sistem baik itu fungsional maupun non fungsional.

\section{Analisis Kebutuhan Fungsional}

Menggambarkan fungsionalitas sistem atau layanan-layanan sistem. Sangat bergantung dari jenis perangkat lunak, pengguna sistem, dan jenis sistem dimana perangkat lunak tersebut digunakan. Berikut adalah uraian perincian dari kebutuhan Fungsional Aplikasi Penjualan Berita :

a. Sistem harus mampu melakukan upload dan download berita.

b. Sistem harus dapat melakukan proses pelelangan yang meliputi:

1. Pemasangan bit harga oleh klien media penyiar.

2. Menampilkan data berita yang meliputi id berita, , dan lokasi kejadian.
3. Pembukaan dan penutupan lelang.

4. Menampilkan bit tertinggi.

c. Sistem harus dapat melakukan registrasi dan edit profile koresponden.

d. Sistem harus dapat memberikan login berbeda untuk koresponden dan perusahaan penyiar.

e. Sistem harus mampu menampilkan halaman fee untuk koresponden dengan rincian:

1. Fee yang tertampil pada halaman koresponden adalah fee yang telah dikurangi oleh aplikasi ini sebesar $10 \%$.

2. Menampilkan judul berita.

3. Menampilkan status transfer fee.

f. Sistem harus mampu menampilkan halaman informasi untuk koresponden.

g. Sistem harus dapat menampilkan profile koresponden dan perusahaan penyiar.

h. Sistem harus mampu menyajikan halaman konfirmasi transfer pembelian berita oleh perusahaan penyiar.

i. Sistem harus dapat memanajemen poinpoin diatas.

j. Sistem harus dapat digunakan oleh koresponden, administrator, dan perusahaan penyiar.

Analisis kebutuhan fungsional diatas kemudian diolah dalam bentuk desain flowchart, DFD, dan ERD yang kemudian diterjemahkan dalam bentuk desain user interface

\section{Tahap implementasi}

Pada tahapan ini desain sistem yang telah disusun sebelumnya diubah menjadi kodekode program dan modul-modul yang nantinya akan diintegrasikan menjadi sebuah sistem yang lengkap sesuai dengan kontrak kerja. 


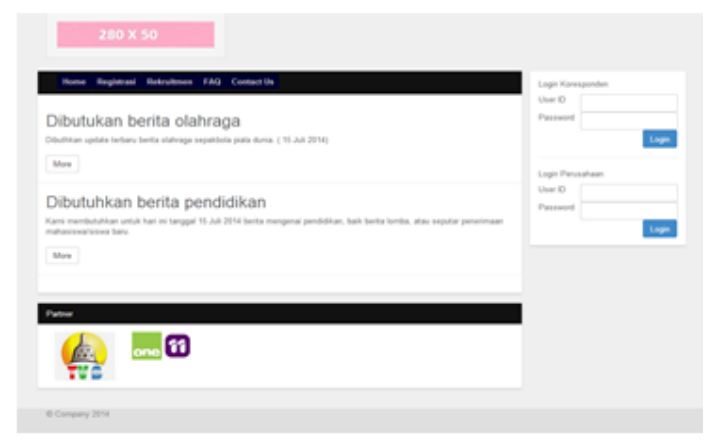

Gambar 3.Tampilan Halaman Home

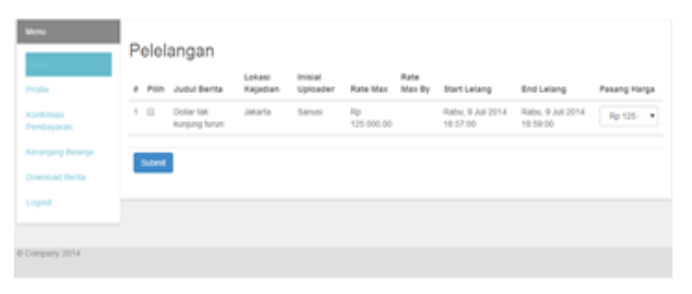

Gambar 4. Tampilan halaman Pelelangan

\section{Tahap integrasi dan testing.}

Tahapan ini dilaksanakan menggunakan metode pengujian blackbox guna memastikan jalannya sistem informasi telah sesuai kontrak.

Tabel 1. Hasil pengujian blackbox

\begin{tabular}{|c|c|c|c|}
\hline No & Nama Menu & $\begin{array}{l}\text { Jenis Unit } \\
\text { Yang di Tes }\end{array}$ & $\begin{array}{l}\text { Hasil } \\
\text { Tes }\end{array}$ \\
\hline 1 & Login & Proses Login & Baik \\
\hline 2 & Home & Tampilan & Baik \\
\hline 3 & Rekruitmen & Tampilan & Baik \\
\hline 4 & Register & Proses Register & Baik \\
\hline 5 & About us & Tampilan & Baik \\
\hline 6 & $F A Q$ & Tampilan & Baik \\
\hline 7 & Contact us & Tampilan & Baik \\
\hline 8 & $\begin{array}{l}\text { Register } \\
\text { koresponden }\end{array}$ & $\begin{array}{l}\text { Proses edit, } \\
\text { lihat, aprove, } \\
\text { reject,tampilan }\end{array}$ & Baik \\
\hline 9 & $\begin{array}{l}\text { Berita dari } \\
\text { koresponden }\end{array}$ & $\begin{array}{l}\text { Proses edit, } \\
\text { lihat, aprove, } \\
\text { reject,tampilan }\end{array}$ & Baik \\
\hline 10 & $\begin{array}{l}\text { Konfirmasi } \\
\text { pembayaran } \\
\text { berita }\end{array}$ & $\begin{array}{l}\text { Proses edit, } \\
\text { aprove, } \\
\text { reject,tampilan }\end{array}$ & Baik \\
\hline 11 & Pelelangan & $\begin{array}{l}\text { Proses edit, } \\
\text { tambah, } \\
\text { tampilan }\end{array}$ & Baik \\
\hline 12 & Konten & $\begin{array}{l}\text { Proses edit, } \\
\text { lihat, tambah, } \\
\text { hapus, } \\
\text { tampilan }\end{array}$ & Baik \\
\hline 13 & $\begin{array}{l}\text { Klien media } \\
\text { penyiar }\end{array}$ & $\begin{array}{l}\text { Proses edit, } \\
\text { lihat, tambah, } \\
\text { hapus, } \\
\text { tampilan }\end{array}$ & Baik \\
\hline
\end{tabular}

\begin{tabular}{|l|l|l|l|}
\hline 14 & $\begin{array}{l}\text { Klien } \\
\text { koresponden }\end{array}$ & $\begin{array}{l}\text { Proses edit, } \\
\text { lihat, tampilan }\end{array}$ & Baik \\
\hline 15 & $\begin{array}{l}\text { Keranjang } \\
\text { belanja }\end{array}$ & $\begin{array}{l}\text { Proses input, } \\
\text { lihat, tampilan }\end{array}$ & Baik \\
\hline 16 & $\begin{array}{l}\text { Kirim link } \\
\text { download }\end{array}$ & $\begin{array}{l}\text { Prose input, } \\
\text { tampilan }\end{array}$ & Baik \\
\hline 17 & Profile & $\begin{array}{l}\text { Proses edit, } \\
\text { tampilan }\end{array}$ & Baik \\
\hline 18 & $\begin{array}{l}\text { Upload } \\
\text { berita }\end{array}$ & $\begin{array}{l}\text { Proses input, } \\
\text { tampilan }\end{array}$ & Baik \\
\hline 19 & Fee & $\begin{array}{l}\text { Lihat, } \\
\text { tampilan }\end{array}$ & Baik \\
\hline 20 & List Berita & $\begin{array}{l}\text { Lihat, } \\
\text { tampilan }\end{array}$ & Baik \\
\hline 21 & Profile & $\begin{array}{l}\text { Proses edit, } \\
\text { lihat, tampilan }\end{array}$ & Baik \\
\hline 22 & $\begin{array}{l}\text { Konfirmasi } \\
\text { pembayaran }\end{array}$ & $\begin{array}{l}\text { Proses input, } \\
\text { tampilan }\end{array}$ & Baik \\
\hline 23 & Informasi & $\begin{array}{l}\text { Proses input, } \\
\text { tampilan }\end{array}$ & Baik \\
\hline 24 & $\begin{array}{l}\text { Keranjang } \\
\text { belanja }\end{array}$ & $\begin{array}{l}\text { Lihat, } \\
\text { tampilan }\end{array}$ & Baik \\
\hline 25 & $\begin{array}{l}\text { Download } \\
\text { berita }\end{array}$ & $\begin{array}{l}\text { Proses } \\
\text { download, } \\
\text { tampilan }\end{array}$ & Baik \\
\hline
\end{tabular}

\section{Kesimpulan dan Saran}

Berdasarkan uraian penjelasan dan pembahasan pada keseluruhan bab pada skripsi "Perancangan dan Pembuatan Sistem Informasi Penjualan Berbasis Web" maka dapat ditarik kesimpulan:

1. Sistem yang diusulkan dapat membantu mempermudah masyarakat dalam menjual suatu informasi/berita ke perusahaan penyiar,

2. Pembuatan Sistem Informasi Penjualan Berbasis Web melalui beberapa tahap yaitu analisis sistem, penentuan kebutuhan fungsional dan non fungsional, pembuatan flowchart sistem, DFD, ERD, database, perancangan interface, dan pembuatan aplikasi.

3. Sistem yang diusulkan dapat membantu perusahaan dalam mendapatkan berita yang aktual, update, dan terpercaya.

Saran diajukan tentang daya tarik peneliti kepada pembaca lain untuk melakukan penyelidikan lebih lanjut. Di sisi lain, perlu memasukkan rekomendasi yang relevan dari temuan penelitian. 


\section{Referensi}

[1] Teguh Wahyono, “ Konsep Dasar, Analisis Desain dan Implementasi" Yogyakarta: GRAHA ILMU, 2004 , 86.

[2] Tata Sutabri, "Analisis Sistem Informasi “ Yogyakarta: ANDI, 2012 ,117.

[3] Indoseraya. (2017, August.7) Pengertian Lelang [online]. Available : https://www.ilmu-ekonomi-id.com
[4] Madcoms, "Aplikasi Manajemen Database Pendidikan Berbasis Web dengan PHP dan MySQL", Yogyakarta: ANDI 2007.

[5] M.Rudyanto Arif, "Pemrograman Basis Data Menggunakan Transact-SQL dengan Microsoft SQL Server 2000", Yogyakarta: ANDI, 2006.

[6] Jogiyanto, "Analisis dan Desain Sistem Informasi", Edisi IV, Yogyakarta : Andi Offset, 2010. 